DOI: https://doi.org/10.24144/2409-6857.2020.1(55).69-74

УДК 338.24(477):332.142+330.34

ББК У9(4Укр)-211

Газуда М.В., Ракович С.С., Сойма С.Ю.

\title{
БАГАТОАСПЕКТНІСТЬ УПРАВЛІНСЬКИХ МЕХАНІЗМІВ У ЗАБЕЗПЕЧЕННІ ПРОСТОРОВОГО РОЗВИТКУ
}

\begin{abstract}
У статті розглянуто окремі аспекти формування механізмів управління просторовим розвитком. У прочесі дослідження узагальнено науково-теоретичні підходи до трактування економічної сутності поняття „механізм управління”. Відмічено, щз при побудові ефективної моделі управління розвитком просторових систем вагомого значення набуває регіональний бенчмаркінг як управлінська технологія $i$ комплексний пошук еталонних управлінських практик для їх впровадження в багатогранних сферах діяльності й господарювання.
\end{abstract}

Ключові слова: механізми управління, просторовий розвиток, управлінська система, пріоритетні галузі, види економічної діяльності

\begin{abstract}
Постановка проблеми. В умовах перманентності змін, складних трансформаційних процесів, що відбуваються нині в економічній системі країни та ії регіонів, окреслення підходів до управління просторовим розвитком $є$ викликом часу і необхідною умовою розвитку територіальної економічної системи. Актуальності набуває формування ефективного управлінського механізму, який сприятиме забезпеченню дієвості функціонування економічної системи в межах просторового регіонального розвитку. При цьому зумовлюється необхідність системного підходу, який охоплюватиме, поряд з соціально-економічною, екологічну, природну й просторову складові розвитку регіону.
\end{abstract}

Аналіз останніх досліджень і публікацій. Науково-теоретичні й методологічні основи організації i забезпечення управлінського процесу, підвищення його дієвості, формування організаційно-економічного й фінансового механізмів управління суб'єктами господарювання досліджено вітчизняними й зарубіжними науковцями, серед них П. Друкер,

(C) Газуда М.В., д.е.н., проф., професор кафедри економіки i підприємництва, ДВНЗ «Ужгородський національний університет», Еmail: misha.gazuda@uzhnu.edu.ua

Ракович С.C., аспірант кафедри економіки і підприємництва, ДВНЗ «Ужгородський національний університет», E-mail: Tauruspiko@gmail.com

Сойма С.Ю., к.е.н., доцент, доцент кафедри бізнес-адміністрування, маркетингу та менеджменту, ДВНЗ «Ужгородський національний університет», E-mail: svitlana.sojma@uzhnu.edu.ua
П. Сгоров,
Й. Завадський,
О. Кендюхов,
О. Ковалюк,
В. Кноррінг,
А. Кульман,

Ю. Лисенко, Б. Мільнер, В. Шатун та ін.

Дослідження концептуальних підходів до побудови механізму системного управління процесами в межах просторового розвитку, територіального управління, організації державного управління здійснено такими науковцями, як О. Балуєв, О. Бобровська, А. Васіна, А. Владзимирський, Р. Ларіна, О. Машков, А. Мельник, О. Оболенський та ін. Вирішення проблемних питань просторового розвитку з використанням аналітичного методу „shift-share” обгрунтовано у наукових працях Т. Трубніка, Кларк В. Рейнольдса та ін.

Наукові дослідження зазначених вчених мають вагоме теоретико-практичне значення. Однак окремих досліджень потребують підходи до формування механізмів управління просторовим розвитком, їх застосування у певних сферах і видах економічної діяльності.

Формулювання цілей статті. Метою статті $\epsilon$ дослідження окремих аспектів формування i реалізації механізмів управління в межах просторового розвитку.

Опис основного матеріалу дослідження. Управлінські механізми в межах регіонального просторового розвитку характеризуються багатоаспектністю, оскільки у процесі функціонування економічної системи під їх вплив підпадають як види економічної діяльності, так і пріоритетні сфери господарювання, що зумовлено необхідністю вирішення проблемних питань територіального розвитку, зокрема соціально-економічних, екологічних, організаційно-правових та ін.

Вирішення проблемних питань просторового розвитку й підвищення ефективності задіяного 
управлінського механізму залежатиме передусім від адекватно і грамотно визначених цілей i успішності їх реалізації. При цьому вагомого значення набуває процес активізації управлінських функцій, зокрема $[4$, с. 18]: планування, організація, розпорядження, координування, контроль, мотивація, керівництво, комунікації, дослідження, оцінювання, прийняття рішень, підбір кваліфікованих фахівців, представництво, ведення переговорів, укладення угод та ін. Функціональність зазначеного процесу посилюється багатоаспектністю механізму управління у різних сферах і видах економічної діяльності розширенням у просторово-часовому вимірі.

Наукове трактування й економічна сутність механізму управління позначаються багатогранністю його змістового наповнення (табл. 1).

Сутнісне розуміння категорії „механізм управління”

Таблиця 1

\begin{tabular}{|c|c|c|}
\hline Автор & Визначення механізму управління & $\begin{array}{c}\text { Аналогічний } \\
\text { підхід }\end{array}$ \\
\hline 1 & 2 & 3 \\
\hline $\begin{array}{l}\text { Г. Атаманчук } \\
{[2, \text { с. } 86]}\end{array}$ & $\begin{array}{l}\text { Складова частина системи управління, що забезпечує вплив на фактори, } \\
\text { від стану яких залежить результат діяльності управлінського об'єкта }\end{array}$ & $\begin{array}{c}\text { Система } \\
\text { управління }\end{array}$ \\
\hline $\begin{array}{l}\text { Г. Астапова, } \\
\text { Е. Остапова, } \\
\text { Д. Лойко } \\
{[1, \text { с. } 279]}\end{array}$ & $\begin{array}{l}\text { Система елементів організаційно-економічного впливу на процес } \\
\text { управління }\end{array}$ & $\begin{array}{l}\text { Система } \\
\text { елементів } \\
\text { управління }\end{array}$ \\
\hline $\begin{array}{l}\text { Р. Ларіна, } \\
\text { А. Владзимирсь-кий, } \\
\text { О. Балуєва }[17, \text { с. } 27]\end{array}$ & $\begin{array}{l}\text { Сукупність таких елементів, як цілі управління; критерії управління; } \\
\text { методи дії на чинники управління; ресурси управління (матеріальні і } \\
\text { фінансові ресурси, соціальний і організаційний потенціали) }\end{array}$ & $\begin{array}{l}\text { Критерії, } \\
\text { методи, } \\
\text { чинники } \\
\text { управління }\end{array}$ \\
\hline $\begin{array}{l}\text { Н. Нижник, } \\
\text { О. Машкова } \\
{[16, \text { с. } 37]}\end{array}$ & $\begin{array}{l}\text { Складова частина системи управління, що забезпечує вплив на фактори, } \\
\text { від стану яких залежить результат діяльності управлінського об’єкта }\end{array}$ & $\begin{array}{l}\text { Система } \\
\text { управління }\end{array}$ \\
\hline $\begin{array}{l}\text { О. Ковалюк } \\
{[11, \text { с. } 22]}\end{array}$ & $\begin{array}{l}\text { Форми, методи, важелі та інструменти, а також нормативно-правове, } \\
\text { інформаційне та політичне забезпечення. }\end{array}$ & $\begin{array}{c}\text { Система } \\
\text { елементів } \\
\text { управління }\end{array}$ \\
\hline \multicolumn{3}{|c|}{ Механізм-и̨е, } \\
\hline $\begin{array}{l}\text { А.Кульман, } \\
{[13, \text { с. } 14]}\end{array}$ & $\begin{array}{l}\text { Система взаємозв'язків економічних явищ, які виникають за певних } \\
\text { умов під впливом початкового імпульсу }\end{array}$ & $\begin{array}{l}\text { Система } \\
\text { взаємо- } \\
\text { зв'язків }\end{array}$ \\
\hline $\begin{array}{l}\text { О. Кендюхов } \\
{[9, \text { с. 33] }}\end{array}$ & $\begin{array}{l}\text { Система ланок, які перетворюють рух одних ланок на необхідний рух } \\
\text { інших, причому існують вхідна та вихідна ланки }\end{array}$ & $\begin{array}{c}\text { Система } \\
\text { ланок }\end{array}$ \\
\hline $\begin{array}{l}\text { Економічна } \\
\text { енциклопедія } \\
{[6, \text { с. } 355]}\end{array}$ & Система, пристрій, спосіб, що визначає порядок певного виду діяльності & $\begin{array}{l}\text { Система, } \\
\text { пристрій, } \\
\text { спосіб }\end{array}$ \\
\hline $\begin{array}{l}\text { Економічний } \\
\text { словник } \\
{[12, \text { с. } 401]}\end{array}$ & $\begin{array}{l}\text { Послідовність станів, процесів, які визначають собою які-небудь дії, } \\
\text { явища; система, пристрій, який визначає порядок якого-небудь виду } \\
\text { діяльності }\end{array}$ & $\begin{array}{l}\text { Процеси, } \\
\text { явища }\end{array}$ \\
\hline \multicolumn{3}{|c|}{ Управління -uе } \\
\hline П. Друкер [5] & $\begin{array}{l}\text { Особливий вид діяльності, що перетворює неорганізований натовп в } \\
\text { ефективну цілеспрямовану і продуктивну групу }\end{array}$ & $\begin{array}{c}\text { Вид } \\
\text { діяльності }\end{array}$ \\
\hline Г. Сльникова [7] & $\begin{array}{l}\text { Особливий вид людської діяльності в умовах постійних змін } \\
\text { внутрішнього та зовнішнього середовища, який забезпечує } \\
\text { цілеспрямований вплив на керовану систему для збереження і } \\
\text { впорядкування її в межах заданих параметрів на основі закономірностей } \\
\text { іії розвитку та дії механізмів самоуправління }\end{array}$ & $\begin{array}{c}\text { Вид } \\
\text { діяльності }\end{array}$ \\
\hline $\begin{array}{l}\text { В. Кноррінг } \\
{[10, \text { с.18] }}\end{array}$ & Найдавніше мистецтво та новітня наука & $\begin{array}{l}\text { Мистецтво i } \\
\text { наука }\end{array}$ \\
\hline $\begin{array}{l}\text { А. Мельник, } \\
\text { О. Оболенський, } \\
\text { А. Васіна } \\
{[17, \text { с. } 20]}\end{array}$ & $\begin{array}{l}\text { Цілеспрямований вплив, необхідний для узгодженої спільної діяльності } \\
\text { людей }\end{array}$ & $\begin{array}{l}\text { Людський } \\
\text { вплив на } \\
\text { окремі } \\
\text { процеси } \\
\end{array}$ \\
\hline В. Шатун [20] & $\begin{array}{l}\text { Осмислений вплив людини на процеси, об'єкти, а також на людей для } \\
\text { надання необхідної спрямованості їх діяльності й одержання бажаного }\end{array}$ & $\begin{array}{l}\text { Людський } \\
\text { вплив на ок- } \\
\text { ремі процеси }\end{array}$ \\
\hline
\end{tabular}


У цілому механізм управління розглядається як система, сформована на основі поєднання критеріїв, методів, чинників, що у процесі управлінської діяльності взаємозумовлюється людським впливом на певні процеси і явища в межах просторового розвитку. До речі, В. Кноррінг у короткому визначенні поєднав обгрунтування двох понять - управління i механізму управління, зазначивши зокрема: „Управління є процесом, а система управління механізмом, котрий забезпечує цей процес" [10, c. 1]. Розкриваючи теоретичні підходи до організації (управління), Б. Мільнер зауважив, що управлінські механізми передбачають „механізм прийняття управлінських рішень”, тобто застосування управлінських технологій $[18$, c. 125] 3 метою вирішення проблемних питань певної сфери діяльності. Обгрунтовуючи змістове навантаження терміну „організаційноекономічний механізм”, Ю. Лисенко та П. Сгоров окреслюють його як систему, за допомогою якої формуються цілі й стимули, що „дозволяють перетворити у процесі трудової діяльності рух (динаміку) матеріальних і духовних потреб членів суспільства на рух засобів виробництва і його кінцевих результатів, спрямованих на задоволення платоспроможного попиту споживачів" [15, с. 86].

Отже, окреслення особливостей і виявлення спільних характерних рис щодо розуміння сутності понять, пов'язаних 3 тлумаченням механізму управління, дає підстави стверджувати, що зазначений механізм організаційно-економічного характеру базується на формуванні складових частин управлінської системи, яка має безпосередній вплив на досягнення результативності наміченої цілі у процесі забезпечення просторового розвитку. При цьому функціональність системи багато в чому залежить від сформованого механізму, кожна з ланок якого в сукупності дає можливість і поштовх до спрямованого руху в багатогранних сферах і видах економічної діяльності. Крім цього, наукове тлумачення управлінського процесу полягає передусім у визначенні його як виду людської діяльності, спрямованої на певні процеси і об'єкти з метою врегулювання підходів до забезпечення іx результативного функціонування.

Результативність управління процесом просторового територіального розвитку залежить від внутрішніх i зовнішніх чинників, що безперервно на нього впливають. Діяльнісний характер процесу формування управлінських механізмів окреслюється за допомогою функцій планування, прогнозування, організування, регулювання, мотивування, контролювання, спрямованих на забезпечення дієвості зазначеного механізму у вирішенні проблемних питань соціально-економічного й екологічного територіального розвитку.

Окремі автори обгрунтовують структурну модель механізму управління на основі системного підходу, виокремлюючи чотири блоки, що складаються $з$ механізмів [3, с. 52]:

$$
\text { превентивних, які охоплюють }
$$

передбачення; інституційні механізми розроблення стратегій, політик, планів і проєктів 3 використанням концепції i принципів збалансованого розвитку; інформаційне i комунікативне забезпечення діяльності в просторі регіону; ідентифікацію стану розвитку з бажаним рівнем; протидію кризовим явищам;

иільових, до яких входить: узгодження інтересів і виокремлення спільних цілей розвитку; формування, стимулювання і реалізація спільних цілей розвитку об'єктів і суб'єктів системи за напрямами розвитку; розподіл ресурсів, забезпечення безпеки; механізм економічного, соціального, екологічного й людського розвитку;

формування $і$ забезпечення системного комплексного впливу, де окреслюється коригування змін $\mathrm{y}$ стратегіях $\mathrm{i}$ практиках розвитку; урегулювання небажаних тенденцій; адміністративні заходи; підтримка і стабілізація розвитку (надання нових можливостей i мотиваційних стимулів, модернізаційні заходи, запровадження нових форм і методів господарювання і розвитку);

функиіональних, що поєднують управління функціями збалансованого розвитку; планування; організацію; мотивування; фінансування; контроль; взаємодію між суб'єктами господарювання; корпоративне управління; управління конкурентоспроможністю; управління якістю результатів плину процесів.

У період постійних змін і трансформацій виникає необхідність формування управлінських механізмів, які в змозі системно і комплексно підходити до забезпечення просторового розвитку, а не реагувати на проблемну ситуацію постфактум, коли потрібно задіяти набагато більше зусиль, ніж у процесі застосування превентивних заходів 3 метою стабілізаційного впливу на розвиток економічної системи. Адекватність підходу в такій ситуації зумовлюється взаємодією між окремими сферами, видами економічної діяльності, структурними підрозділами організацій i владними структурами, органами місцевого 
самоврядування, територіальними громадами, що в сукупності сприятиме поєднанню інтересів всіх названих складників у забезпеченні тривалого розвитку просторової системи на перспективу. При цьому дієвість механізму управління просторовим розвитком підсилюватиметься обов'язковим урахуванням специфіки й особливостей територіальної системи, іiі конкурентних переваг, інвестиційної привабливості, можливостей розвитку малого i середнього бізнесу як вагомих складових забезпечення економічного зростання території.

Сутнісні підходи до обгрунтування механізму управління в окремо взятій сфері, до прикладу у процесі використання відновлюваних природних ресурсів в аграрному секторі, окреслюють як [4, c. 27]: систему взаємопов'язаних методів, принципів, інструментів управління процесами природокористування, що визначають порядок дій у забезпеченні сталого розвитку природних ресурсів у сільському господарстві. При цьому зазначається, що управлінський механізм у сфері аграрного господарювання повинен враховувати зростаючі потреби у природних ресурсах та їх наявні обсяги, що уможливить оптимізацію процесу природокористування i сприятиме збереженню його для прийдешніх поколінь. Водночас дієвість управлінського механізму в зазначеній сфері залежатиме від гармонійного поєднання інтересів і потреб соціальної, економічної й екологічної складової просторового розвитку, де забезпечуватиметься високий рівень ведення сільського господарства й культури землеробства на основі розширеного відтворення органічної (екологічно чистої) продукції, інтеграції земельних і біологічних ресурсів, формуючи єдиний об’єкт управлінської діяльності.

У сфері управління фінансами формування досліджуваного механізму базується на врахуванні методичних підходів, що стосуються планування, прогнозування, інвестування, кредитування ін., застосуванні відповідних важелів (прибуток, дохід, санкції, ціни та інші), інформаційного забезпечення тощо [8, с. 167].

Дослідження підтверджує, що при побудові ефективної моделі управління розвитком просторових систем вагомого значення набуває регіональний бенчмаркінг як управлінська технологія i комплексний пошук еталонних управлінських практик для їх впровадження в багатогранних сферах діяльності й господарювання. Важливим при цьому $\epsilon$ виявлення тих підходів у забезпеченні територіального розвитку, які задекларовані й характеризуються досконалістю їх впровадження.

3 метою виявлення структурних зрушень у межах економічної системи у процесі формування регіонального бенчмаркінгу стосовно просторового розвитку часто застосовують такий економіко-географічний метод, як ,shift-share”, що дає змогу здійснити в динаміці оцінювання частки кожної із сфер чи видів економічної діяльності в регіоні і виявити якісний склад цих зрушень. У науковій літературі обгрунтовують сутність методу ,shift-share”, який полягає у:

виявленні відмінностей впливу на функціонування територіальної одиниці національних умов розвитку, галузевих трендів та специфічної регіональної структури [19];

- кількісному вивченні відмінностей у зміні (зростанні або зменшенні) зайнятості між територіальними одиницями за рахунок трьох факторів: національних трендів, галузевої структури та специфічних регіональних умов розвитку [21].

Оскільки бенчмаркінгові технології передбачають не тільки оперативний бенчмаркінг, при якому використовуються наявні регіональні можливості, а й формування стратегічних перспектив, то у процесі розроблення останніх доцільно визначати конкурентоспроможність розвитку територій 3 огляду на унікальні потенційні можливості розширеного відтворення пріоритетних галузей i видів економічної діяльності, де поряд 3 природним, економічним, соціальним, екологічним потенціалом задіяно інтелектуальні ресурси, акумульовані у людському потенціалі й людському капіталі, що дають поштовх до економічного зростання території і країни в цілому.

Висновки i перспективи подальших досліджень. Таким чином, проведене дослідження дає підстави стверджувати, що формування дієвих механізмів управління просторовим розвитком повинно базуватися на системному підході з урахуванням специфічних властивостей території та пріоритетних видів економічної діяльності, для яких є передумови перспективного зростання. Вагомого значення набуває застосування механізмів управління просторовим розвитком, що мають превентивноцільовий, функціональний характер, 3 формуванням i забезпеченням системного комплексного впливу. При цьому функціональність управління передбачає заходи 3 планування, організації, мотивації і контролю процесів i явищ, що відбуваються в межах просторового розвитку. Зумовлюється 
необхідність задіяння бенчмаркінгових технологій, що враховуватимуть, поряд із соціально-економічним, природно-екологічним потенціалом території, інтелектуальні ресурси, акумульовані в людському потенціалі і людському капіталі в межах просторової економічної системи. При цьому доцільність формування i подальшого удосконалення управлінських механізмів, підвищення їхньої дієвості зумовлюється перманентним впливом зовнішнього і внутрішнього середовища в межах досліджуваного розвитку. Подальші наукові розвідки стосуватимуться пошуку й обгрунтування побудови ефективної моделі управління розвитком просторових систем.

\section{ПЕРЕЛІК ВИКОРИСТАНИХ ДЖЕРЕЛ}

1. Астапова Г.В., Астапова Е.А., Лойко Д.П. Организационно-экономический механизм корпоративного управления в современных условиях реформирования экономики Украины: монография. Донецк: ДонГУЭТ им. М. Туган-Барановского, 2001. $526 \mathrm{c}$.

2. Атаманчук Г.В. Теория государственного управления. М. : Юридическая литература, 1997. 400 с.

3. Бобровська О. Механізм системного управління процесами розвитку територій регіонів: концептуалізація конструювання і побудови// Державне управління та місцеве самоврядування. 2017. Вип. 2(33). C. $48-55$.

4. Газуда М. В. Управління використанням відновлюваних природних ресурсів в аграрній сфері: монографія. Ужгород: ДВНЗ „УжНУ”, 2018. 200 с.

5. Друкер Питер Ф. Задачи менеджмента в XXI веке: пер. с англ. М.: Изд. дом «Вильямс», 2003. 313 с.

6. Економічна енциклопедія : [у 3 т.]. Київ : Видавничий центр "Академія", 2002/гол. ред. ради : Гаврилишин Б. Д. [та ін.]. Т. 2 / [відп. ред. Мочерний С. В.]. 2002. 952 с.

7. Сльникова Г.В. Наукові основи розвитку управління загальною середньою освітою в регіоні : монографія. К. : ДАККО, 1999. 303 с.

8. Завадський Й. С. Менеджмент. К.: Український інститут менеджменту і бізнесу, 1997. Т. 1. 543 с.

9. Кендюхов О. Сутність і зміст організаційно-економічного механізму управління інтелектуальним капіталом підприємства // Економіка України. 2004. № 2. С. 33-41.

10. Кнорринг В. И. Искусство управления : [учебник]. М. : Изд-во БЕК, 1997. 264 с.

11. Ковалюк О. М. Фінансовий механізм організації економіки України (проблеми теорії і практики): монографія. Львів: Видавничий центр Львівського національного університету ім. Івана Франка, 2002. 396 с.

12. Краткий экономический словарь / под ред. А. Н. Азрилияна. М. : Ин-т нов. экономики, 2001. 1088 с.

13. Кульман А. Экономические механизмы. М.: Прогресс, Универс, 1993. С. 13-14.

14. Ларіна Р.Р., Владзимирський А. В., Балуєва О. В. Державний механізм забезпечення інформатизації системи охорони здоров'я: монографія /під заг. ред. В. В. Дорофієнко. Донецьк : Цифровая типография, 2008. $252 \mathrm{c}$.

15. Лисенко Ю., Єгоров П. Організаційно-економічний механізм управління підприємством// Економіка України. 1997. № 1. С. 86-97.

16. Нижник Н. Р., Машков О. А. Системний підхід в організації державного управління : [навч. посіб.] / за заг. ред. Н. Р. Нижник. К. : Вид-во УАДУ, 1998. 160 с.

17. Мельник А. Ф., Оболенський О. Ю., Васіна А. Ю. Державне управління : підручник/ за ред. А. Ф. Мельник. К. : Знання, 2009. 582 с. (Вища освіта XXI століття).

18. Мильнер Б. З. Теория организаций. М: ИНФРА, 1998. 336 с.

19. Трубнік Т.Є. Використання методу "Shift'Share" аналізу для оцінювання якості секторальних зрушень//Електронне наукове фахове видання "Ефективна економіка". 2012. № 7. URL: http://www.economy.nayka.com.ua/?op=1\&z=1281\&p=1

20. Шатун В. Т. Основи менеджменту: навч. посіб. Миколаїв : Вид-во МдГУ ім. Петра Могили, 2006. 376 с.

21. Clark W. Reynolds. A shift-share analysis of regional and sectoral productivity growth in contemporary Mexico. Laxenburg, Austria: International Institute for Applied Systems Analysis, 1980. 55 p.

\section{REFERENCES}

1. Astapova H., Astapova E., Loiko D. (2001) Organizatsionno-ekonomicheskiy mehanizm korporativnogo upravleniya v sovremennyih usloviyah reformirovaniya ekonomiki Ukrainyi: monografiya [Organizational and economic mechanism of corporate governance in the modern conditions of reforming the Ukrainian economy: monograph]. Donetskyi natsionalnyi universytet ekonomiky ta torhivli M. Tuhan-Baranovskoho [Mychailo Tuhan-Baranovskyi Donetsk National University of Economics and Trade]. Donetsk [in Russian].

2. Atamanchuk G. (1997) Teoriya gosudarstvennogo upravleniya [The government theory]. Yuridicheskaya literatura [Legal literature], Moskov [in Russian].

3. Bobrovska O. (2017) Mekhanizm systemnoho upravlinnia protsesamy rozvytku terytorii rehioniv: kontseptualizatsiia konstruiuvannia i pobudovy [System management mechanism in processes of region territories 
development: design and encouragement conceptualization]. Derzhavne upravlinnia ta mistseve samovriaduvannia [Public administration and local government], 2 (33), 48-55 [in Ukrainian].

4. Hazuda M. V. (2018) Upravlinnia vykorystanniam vidnovliuvanykh pryrodnykh resursiv $\mathrm{v}$ ahrarnii sferi: monohrafiia [Management of the usage of renewable natural resources in agricultural sector: monograph] Uzhhorodskyi natsionalnyi universytet [Uzhgorod National University][in Ukrainian].

5. Druker P. (2003) Zadachi menedzhmenta v XXI veke: per. s angl. [Management tasks in the XXI century: trans. from Eng.] Williams, Moskov [in Russian].

6. Havrylyshyn B. (2002) Ekonomichna entsyklopediia: (u 3 t.) [Economic encyclopedia (in 3 V.)] Akademiia [Academy], Kyiv [in Ukrainian].

7. Yelnykova H. V. (1999) Naukovi osnovy rozvytku upravlinnia zahalnoiu serednoiu osvitoiu v rehioni : monohrafiia [Scientific basis for the development of management by the middle of the world in the region: monograph] Dakko, Kyiv [in Ukrainian].

8. Zavadskyi Y. S. (1997) Menedzhment, т.1 [Management, V 1.] Ukrainskyi instytut menedzhmentu i biznesu [Ukrainian Institute of Management and Business], Kyiv [in Ukrainian].

9. Kendiukhov O. (2004) Sutnist i zmist orhanizatsiino-ekonomichnoho mekhanizmu upravlinnia intelektualnym kapitalom pidpryiemstva [Essence and change of the organizational and economic mechanism of the enterprece's intellectual capital management] Ekonomika Ukrainy [Economy of Ukraine], 2, 33-41 [in Ukrainian].

10. Knorring V. (1997) Iskusstvo upravleniya [The art of management], Izdatelstvo BEK [BEK Publishing House], Moskov [in Russian].

11. Kovaliuk O. (2002) Finansovyi mekhanizm orhanizatsii ekonomiky Ukrainy (problemy teorii i praktyky): monohrafiia [Financial mechanism of organizing the economy of Ukraine (problems of theory and practice): monograph] Vydavnychyi tsentr Lvivskoho natsionalnoho universytetu im. Ivana Franka [Publishing center of The I. Franko University of Lviv], Lviv [in Ukrainian].

12. Kratkiy ekonomicheskiy slovar /pod red. A. N. Azriliyana (2001) [Brief economic dictionary], Inctitut novoy ekonomiki [The Institute for New Economy], Moskov [in Russian].

13. Kulman A. (1993) Ekonomicheskie mehanizmyi [Economic mechanisms], Progress Univers (Progress Universe), [in Russian].

14. Larina R., Vladzymyrskyi A., Baluieva O. (2008) Derzhavnyi mekhanizm zabezpechennia informatyzatsii systemy okhorony zdorov'ia: monohrafiia [The sovereign mechanism for securing the informatization of the health protection system: monograph], Tsifrovaya tipografiya [Digital typography] [in Ukrainian].

15. Lysenko Y, Yehorov P. (1997) Orhanizatsiino-ekonomichnyi mekhanizm upravlinnia pidpryiemstvom (Organizational and economic mechanism of enterprise's management), Ekonomika Ukrainy [Economy of Ukraine], 1, 86-97 [in Ukrainian].

16. Nyzhnyk N., Mashkov O. (1998) Systemnyi pidkhid v orhanizatsii derzhavnoho upravlinnia (navch. posib.) [System approach in the organization of public administration], Vydavnytstvo Ukrainskoi akademii drukarstva [Publishing house of the Ukrainian Academy of Printing], Kyiv [in Ukrainian].

17. Melnyk A., Obolenskyi O., Vasina A. (2009) Derzhavne upravlinnia : pidruchnyk [Public administration: a textbook], Znannia [Knowledge] [in Ukrainian].

18. Milner B. (1998) Teoriya organizatsiy [Theory of organizations], INFRA, Moskov [in Russian].

19. Trubnik T. (2012) Vykorystannia metodu "Shift'Share" analizu dlia otsiniuvannia yakosti sektoralnykh zrushen [Usage of the "Shift'Share" analysis method to assess the quality of sectoral changes], Efektyvna ekonomika [Efficient economy], 7 [in Ukrainian]

URL. <http://www.economy.nayka.com.ua/?op=1\&z=1281\&p=1>

20. Shatun V. (2006) Osnovy menedzhmentu [Fundamentals of management] Vydavnytstvo Chornomorskoho natsionalnoho universytetu im. P. Mohyly [Publishing house of the P. Mohyla Black Sea National University], Mykolayiv [in Ukrainian].

21. Clark W., Reynolds. A. (1980) A shift-share analysis of regional and sectoral productivity growth in contemporary Mexico. Laxenburg, Austria: International Institute for Applied Systems Analysis [in English] 